\title{
BREVES APONTAMENTOS SOBRE OS PRINCÍPIOS EM MATÉRIA DE DIREITOS POLÍTICOS E ELEITORAIS
}

\section{Gabriel Vieira Terenzi ${ }^{1}$}

RESUMO: Tem o objetivo de tratar da relação entre os ramos dos Direitos Políticos e do Direito Eleitoral. Assim, por meio da análise dos conceitos e características de cada feixe, pretende-se delimitar suas áreas convergentes, divergentes, e sua finalidade, mais especialmente debater-se a noção de serem as normas eleitorais tidas como instrumentos de efetivação dos direitos políticos e, em última análise, da soberania popular. A fim de alcançar esse objetivo, utilizar-se-á uma abordagem principiológica para definir os conceitos e tratar do tema, concluindo-se pela utilidade instrumental da interpretação eleitoral como medida garantidora da soberania do povo e da democracia.

PALAVRAS-CHAVE: Princípios; Direitos Políticos; Direitos Eleitorais; Interpretação; Instrumental.

\section{BRIEF NOTES ON THE PRINCIPLES WITH REGARD TO POLITICAL AND ELECTORAL RIGHTS}

ABSTRACT: The purpose is to address the relationship between the branches of Political Rights and Electoral Law. Thus, through the analysis of the characteristics of each bundle, is intended to delimit its areas, and their purpose, especially to debate the notion that the electoral norms are seen as instruments for the realization of political rights and of popular sovereignty. In order to achieve this objective, a principled approach will be used to define the concepts and address the theme, concluding by the instrumental utility of electoral interpretation as a measure that guarantees the sovereignty of the people and democracy.

KEY-WORDS: Principles; Political Rights; Electoral Rights; Interpretation; Instrumental

\section{INTRODUÇÃO}

“Todo poder emana do povo", é o que consagra nossa Constituição ${ }^{2}$. O grande desafio, evidentemente, se encontra em como efetivar essa intenção constituinte de modo concreto. A problemática não é despida de desafios: por um lado, se encara um descontentamento entre os resultados obtidos pelo crivo democrático, seja na satisfatividade

\footnotetext{
${ }^{1}$ Mestrando em Ciência Jurídica na linha de pesquisa Função Política do Direito pela UENP - Universidade Estadual do Norte do Paraná. Rua Manoel Góes, nº 309, Santa Rosa, Valparaiso, SP, CEP. 16880-000. gabrielvterenzi@gmail.com.

${ }^{2}$ Art. $1^{\circ}$, caput, da Constituição da República Federativa do Brasil de 1988.
} 
da opinião obtida pela deliberação, seja pela necessária representação de parcelas minoritárias ou de grupos vulneráveis.

Igualmente, não se pode olvidar que a democracia representativa não se reveste unicamente de um caráter plebiscitário, cabendo, necessariamente um grau de discricionariedade na atuação dos poderes constituídos, nem sempre compreendidos ou aceitados pelos constituintes.

Dado esse quadro, nos Estados modernos, tendo em vista a atualização até mesmo da concepção constitucional, parece cada vez mais ser necessário recorrer-se à dimensão jurídica, inclusive pela jurisdição propriamente dita, na arguição de temas referentes a essa seara deliberativa. Assim, necessário que a própria ciência jurídica debata essa função que passa a avocar, nos ramos políticos e eleitorais, de modo a não haver o desbordamento de sua atuação, a qual não se encontra desprovida de balizas. Quanto menos definidas tais balizas, tanto maiores os riscos de que sejam ultrapassados os limites de maneira casuística.

Diante do caráter notadamente hermenêutico dos Princípios, a eles se encontram vinculados, talvez, mais intensamente, aqueles riscos. Afinal, muito embora sejam os preceitos de serventia na percepção axiológica das normas, uma vez incompreendidos estes, os princípios ao contrário de auxílio, tornar-se-ão óbices à real percepção das regras em questão. Dizem pouco ou nada, quando não considerada a verdadeira função das eleições.

O presente objetiva debruçar-se sobre tema pouco tratado na seara eleitoral, qual seja a relação do ramo com os direitos políticos, e os desdobramentos dessa interação com a interpretação dos princípios eleitorais, segundo a linha de raciocínio finalística, de ser o sistema jurídico eleitoral instrumento de efetivação da soberania popular.

\section{APONTAMENTOS SOBRE OS DIREITOS POLÍTICOS E ELEITORAIS}

É interessante notar que, de modo geral, pouco se debate na academia a relação entre os direitos políticos e eleitorais, ou mesmo entre a posição ocupada pelos respectivos ramos da ciência jurídica:

Essa omissão, no entanto, não causa estranheza, já que a própria temática dos direitos políticos como direitos fundamentais carece de maiores reflexões, não somente por parte da doutrina especializada, mas, sobretudo, pelas Cortes eleitorais (BASTOS JÚNIOR; SANTOS, 2015).

Ao contrário do que seria esperado de tema de tal relevância, o constitucionalismo contemporâneo tem se debruçado com pouca intensidade a respeito da conceituação e 
interpretação deste feixe jurídico. Mais estarrecedor, é o pouco interesse que despertam os direitos políticos na Doutrina Eleitoralista.

Muito embora qualquer tomo desta seara possua alguns poucos parágrafos dedicados aos direitos políticos, não se costuma extrair a relação entre os ramos, embora seja esta relação determinante para a produção, interpretação e aplicação de qualquer norma eleitoral.

Não bastasse, na senda principiológica a fissura se aprofunda, com a utilização muitas vezes inadequada, mas frequentemente mal compreendida de preceitos daquele em relação a este ramo e vice e versa, para não mencionar a evidente má interpretação desses princípios, comumente invocados sem o menor aprofundamento axiológico.

\subsection{SOBERANIA POPULAR: UMA BREVE CONCEITUAÇÃO}

Quanto aos direitos políticos em si, inegável tratarem-se de normas intimamente ligadas à colocação em prática da Soberania Popular, assim se faz necessário a abordagem do tema.

O significado dessa soberania, no entanto, vai além, pois sendo o povo o seu único detentor, é também dele que decorre a legitimidade do Estado. É nesse sentido a determinação da Constituição de que a soberania "será exercida pelo sufrágio universal e pelo voto direto e secreto, com valor igual para todos"3.

Carta como fundamento da República, ou seja, nossa ordem política e social se erige acima da ideia de que aos cidadãos cabe a decisão de como será determinada essa mesma ordem. Inobstante, estabeleceu-se ainda o modo como será esse poder externado e aferido, qual seja, o sufrágio que englobe a todos os cidadãos por meio de suas manifestações diretas e sigilosas, com equidade de valor. Sucintamente, é a soberania popular "que confere legitimidade ao exercício do poder estatal. Tal legitimidade só é alcançada pelo consenso expresso na escolha feita nas urnas (GOMES, 2018b, p. 73).

Somente com a observância daquele estabelecimento é que resta legítimo o poder público. Daí decorre a razão de ser dos direitos políticos, os quais emanam como garantias, efetivações e, em determinadas situações, balizas ao exercício da soberania popular, como veremos a seguir.

\footnotetext{
${ }^{3}$ Artigo 14, caput, Constituição da República Federativa do Brasil de 1988.
} 


\subsection{O CONCEITO DE DIREITOS POLÍTICOS}

Definido o ideal de soberania popular, cabe destacar quanto aos direitos políticos, serem estes intrinsecamente ligados a tal conceito. Compõem este ramo as normas jurídicas que possibilitam e protegem a externalização da soberania; que determinam e dão forma ao modo de sua prática, e ainda as normas que a excepcionam.

Se o conceito de soberania popular é inalienável à nossa atual sociedade, sendo um fundamento de qualquer estado democrático de direito, daí emanam normas que visam resguardar esse bem jurídico. Assim, direitos políticos definem as regras e princípios que a um só tempo reservam ao povo, como conjunto de cidadãos, a possibilidade de influência política, e ainda aquelas normas que estabelecem essa influência.

Nos parece acurada a definição de que o conjunto expressa "os direitos da nacionalidade e os de participação política, que se sintetizam no direito de votar e ser votado" (BARROSO, 2010, p. 209). Se a soberania é inerente à liberdade pessoal, como garantia de dignidade humana, os direitos políticos que a corporificam devem ser tidos como direitos fundamentais ao indivíduo. Assim, por obviedade, devem ser encarados como integrantes dos Direitos Humanos - no âmbito internacional - e dos Direitos Fundamentais - internamente.

Por metodizarem a vontade popular, ou seja, garantirem em última análise a própria possibilidade de que um indivíduo seja capaz de interferir no ordenamento que sobre ele impera, devem ser tidos os direitos políticos como imprescindíveis à dignidade de qualquer ser humanos. Nós os possuímos não porque o Estado assim o decidiu, mediante suas leis, mas porque sem estes não seria legítima a instituição estatal erigida.

Para os adeptos de tal taxonomia, os Direitos Humanos podem ser divididos em gerações: "Cada geração foi associada, na Conferência proferida por Vasak, a um dos componentes do dístico da Revolução Francesa: "liberté, egalité et fraternité" (liberdade, igualdade e fraternidade)" (RAMOS, 2017, p. 53).

Ora, nesta primeira dimensão, calcada em um ideal de liberdade, necessário se faz que o Estado-interventor abstenha-se de interferir nas decisões populares, o que é consoante com a própria ideia de soberania popular. Essa necessidade não é uma consequência da taxinomia dos direitos políticos como humanos de primeira dimensão. Antes, a necessidade de abstenção estatal é justamente a causa de ser aquele ramo jurídico assim classificado. E a razão dessa imposição de não-intervenção é a própria finalidade do valor preceituado, a livre e legítima manifestação de vontade soberana do povo. 
Mais interessante que a mera classificação, é a noção de que, a partir do momento em que se coadunam os direitos políticos como parcela dos humanos, toda a metodologia, as características, e técnicas de arguição e efetivação deste último ramo, aplicam-se àquele. E de que aspectos estamos tratando? Vejamos.

Pela própria natureza de essencialidade dos temas aos quais se debruça o feixe jurídico em análise, decorrem como suas características, dentre diversas outras as quais deixam de ser citadas por não comporem o cerne do presente, a universalidade, a centralidade, superioridade (preferenciabilidade) e a reciprocidade.

Por universais, tem-se a própria definição de Direitos Humanos, dos quais são sujeitos todo e qualquer indivíduo, independentemente de qualquer critério segregacional que possa vir a ser utilizado, e destes nunca poderá se ver definitivamente privado. Não é necessário a um Estado - embora seja pertinente que o faça - estabelecer aos seus cidadãos um direito humano para que tal garantia possa ser exigida. Igualmente, não necessita o sujeito pactuar a aplicação dessas normas, fazendo jus à elas pela mera identificação como ser humano.

Já que centrais, as regras e garantias de Direitos Humanos devem ocupar posição de destaque em qualquer ordenamento jurídico. Aqui não se trata necessariamente de destaque hierárquico - como será abordado - mas de privilégio topográfico, hermenêutico e lógico na construção legislativa e jurídica. As normas, privadas e especialmente as públicas, devem estabelecer-se em camadas sobrepostas ao núcleo fundamental de direitos individuais indisponíveis (sejam este Humanos ou Fundamentais). De tal modo que muito embora possa- se flexibilizar tais regras - pela alteração, por exemplo, de normas que não tratem de direitos fundamentais - esta interferência não viole o cerne nuclear mínimo que dignifica o ser humano.

Por superioridade sim tem-se que aos Direitos Humanos não submetem-se aquelas normas que residualmente não são ao ramo enquadradas. Ora, se sem este rol não há dignidade humana, deve este possuir hierarquia distinta, devendo ceder, in casu, todas as normas que com o feixe não se coadunem. Ademais, também por essa estatura não há como ordenar os direitos humanos em importância, cabendo a sua compatibilização em havendo colisão.

Finalmente, por reciprocidade, tem-se que podem estes direitos serem exigidos em relações verticais do indivíduo para com o Estado, mas também horizontais, entre seus sujeitos. É claro que diante desse modesto panorama, nutre-se de tais características o ramo 
dos Direitos Políticos. Evidentemente que torna-se contemporaneamente inconcebível uma instituição estatal não fundada na vontade do seu povo, o que somente se verifica em Estados de Exceção, sendo nesse sentido consagradas universalmente as garantias individuais e políticas. Igualmente os direitos políticos possuem destaque em qualquer instrumento internacional, bem como nas próprias Cartas constitucionais.

Quanto à superioridade hierárquica, já foi demonstrado que em nossa Lei Maior o feixe jurídico integra o título de maior fundamentalidade. Finalmente, a reciprocidade se evidencia pela exigibilidade que emana da aplicação dos direitos políticos: enquanto se confere legitimidade ao Poder Público por meio da vontade popular, cabe ao povo exigir também do Estado o respeito a essa vontade.

Daí oportuno a identificação do lastro normativo do ramo. Pois bem, já foi traçada a soberania popular como fundamento de nossa nação, desde o Artigo $1^{\circ}$, parágrafo único, da Constituição. É no também já citado artigo 14 e seguintes da Carta que se encontra a definição do feixe.

\subsection{A CARACTERIZAÇÃO DOS DIREITOS POLÍTICOS}

Como normalmente se dá com normas de direitos humanos - aqui, fundamentais, por se tratar de instrumento nacional e não internacional de proteção - as regras e princípios ora em análise são, de certo modo, genéricos, justamente cabendo à lei analiticamente determiná-los (torná-los determinados).

Na Constituição de 1988, tem-se no caput do artigo 14 os conceitos gerais do ramo, qual seja, a de que a já abordada soberania será exercida "pelo sufrágio universal e pelo voto direto e secreto, com valor igual para todos". Assim, tem-se já como bases dos direitos políticos o sufrágio, como forma de aferição da vontade popular; a universalidade de sua aplicação; a necessidade de que o voto se dê diretamente do eleitor ao eleito, com sigilo; e a que cada voto comporte a mesma influência ao resultado.

"Sufrágio" já foi bem definido como "o direito público subjetivo democrático, pelo qual um conjunto de pessoas - o povo - é admitido a participar da vida política da sociedade, escolhendo os governantes ou sendo escolhido para governar" (GOMES, 2018b, p. 75).

Já a sua universalidade é característica que se traduz na extensão máxima de sujeitos compreendidos. Ora, o sufrágio, como essência dos direitos políticos, é justamente o conceito nuclear de que o povo deve escolher seus representantes, mas também que representantes 
devem ser escolhidos pelo povo - ou seja, compreende não só a capacidade política ativa, de votar, mas também a passiva, de ser votado. Nesse sentido, o sufrágio universal é aquele que possibilita a participação irrestrita de votantes e votados.

Por óbvio, não será jamais total o sufrágio. Não se quer com este conceito pressupor que votaria um bebê de colo, nem que aquele incapaz de cotidianamente exercer sua vontade irá sufragar. A nomenclatura universal faz supor, em verdade, que as limitações ao exercício dessa capacidade deverão ser homogeneamente distribuídas, pautadas em critérios objetivos, prezando sempre pelo preceito de odiosa restringenda favorabilia amplianda, ou seja, a menor restrição adequada à maior possibilidade de agasalho.

Quanto ao voto, o mesmo se revela justamente como uma espécie de veículo ao sufrágio. Este último poderia ser aferido de diversas maneiras, por aclamação, por supostas atribuições divinas coletivamente presenciadas, pelo reconhecimento social, dentre outras. Consagrou-se, entretanto, o voto, como ferramenta apta a efetivar um sufrágio majoritário de maneira moderna, justa e autêntica.

O texto constitucional optou ainda por atribuir duas qualidades indissociáveis ao voto, o seu sigilo e o fato de ser este direto. A democracia direta é justamente aquela em que os representantes populares são eleitos pelo coletivo soberano sem intermediação.

É claramente o modelo que mais conserva a autenticidade do sufrágio, pois se concebermos analogicamente a soberania como uma energia que emana do povo e se dissipa cada vez que é transferida, o voto direto retém ao seu eleito a maior carga de legitimidade. Já a possibilidade de eleições indiretas, que já foi prevista anteriormente em nossa história constitucional, ainda resta estabelecida em determinadas situações excepcionais, como no caso de vacância do cargo de Presidente da República nos dois últimos anos do mandato ${ }^{4}$.

Quanto ao sigilo, tal preceito é indissociável à honestidade eleitoral. Sem a determinação de serem sigilosas as votações, poder-se-ia exercer diversas modalidades de pressão autoritária ao votante, bem como tornar-se-ia ainda mais fácil a comercialização espúria do voto. Por outro lado, indiscutível também que a publicidade do voto afeta a sua espontaneidade, na medida em que se possibilitam represálias.

Finalmente, o voto com valor igual para todos é predicado essencial de isonomia e de soberania popular. Se as vontades de sujeitos diversos contivessem força diversa, a universalidade do sufrágio perderia a razão de ser, bem como a opção pelo vetor majoritário, e o próprio conceito de soberania se esfacelaria já que não caberia mais aos cidadãos, como

\footnotetext{
${ }^{4}$ Artigo 81, § 1º da Constituição da República Federativa do Brasil de 1988
} 
coletivo difuso, a interferência política.

Os dispositivos que sucedem o analisado artigo 14 constitucional, tratam de temas correlatos aos direitos políticos. A princípio, instituem-se o plebiscito, o referendo e a iniciativa popular como modalidades de exercício de sufrágio. Tais medidas são instrumentos essenciais a uma participação democrática efetiva. $\mathrm{O}$ eleitor moderno, em contraposição ao mero direito de sufragar, "almeja mais e dispõe de instrumentos para tanto" (MESSA; SIQUEIRA NETO; BARBOSA, 2015, p. 92).

Nessa diapasão, dispositivos como os mencionados são bem-vindos pois aproximam o votante da efetiva influência institucional. Lamentavelmente, há uma relativamente baixa frequência de utilização dos mesmos em nossa cultura jurídica.

Ademais, aquela norma firma ainda a obrigatoriedade do voto. Essa concepção do voto como exigência é tema delicado, que escapa dos propósitos presentes, nos quais buscase apenas definição dos direitos políticos e suas interseções. Assim, em tal sede, a compulsoriedade do voto deve ser tida em mente como obrigação inseria no contexto dos direitos políticos, a qual tem como objetivo garantir que o sufrágio alcance um maior número de eleitores. A efetividade dessa intenção, bem como seus méritos e inconvenientes, são temas que merecem debate mais maduro.

O texto Constitucional optou ainda por estabelecer critérios a pautar a aquisição de capacidade política ativa e passiva, ou seja, critérios que erigem o cidadão à qualidade de eleitor, bem como medidas que determinem a elegibilidade e a inelegibilidade. Tais matérias encontram-se indissociavelmente inseridas no rol de direitos políticos, já que diante dessas normas é que definem-se os protagonistas do cenário democrático, bem como o modo como podem atuar.

Finalmente, o dispositivo designa à lei complementar definir hipóteses diversas de inelegibilidade como forma de garantir a moralidade administrativa, e ações próprias de impugnar o mandato eletivo.

Por sua vez o artigo 15 da Constituição Federal tem a finalidade de definir hipóteses de perda e suspensão dos direitos políticos, ao passo em que promove a proibição de sua cassação. Tanto a cassação quando a perda são modalidades de privação definitiva de tais direitos, sendo que o que as difere é justamente a possibilidade de retomada. Assim inconstitucional a cassação justamente por seu absolutismo. Já a suspensão, que como a perda é admitida pela Carta, traduz-se na privação temporária, sendo que quem a esta se submete, após prazo ou condição, retoma o exercício dos direitos políticos automaticamente. 
Daí surge importante classificação deste feixe, segundo a qual os direitos políticos podem ser concebidos ora como positivos ora como negativos. Os primeiros se referem a todas as hipóteses que justamente garantem ou regulam o exercício da soberania popular. Residualmente, direitos políticos negativos são aqueles que "negam, ao cidadão, o direito de eleger, ou de ser eleito, ou de exercer atividade político partidária ou de exercer função pública" (SILVA, 2007, p. 348).

É evidente que qualquer norma que regule um direito político em verdade pode ser tida como positiva ou negativa concomitantemente, a depender de sua visualização. A regra que estabelece a idade mínima de 16 anos para o voto atribui um direito político positivo a todos aqueles que adimplam essa condição de ordem cronológica. Ao mesmo tempo, in contrario sensu aqueles que ainda não superaram aquele critério etário suportam a incidência, pela mesma norma, de um direito político negativo.

O último artigo do tópico (que, como visto, não alberga necessariamente todas as normas constitucionais a respeito dos direitos políticos) trata em verdade do princípio da anualidade em matéria eleitoral, segundo o qual "A lei que alterar o processo eleitoral entrará em vigor na data de sua publicação, não se aplicando à eleição que ocorra até um ano da data de sua vigência",

O mandamento em questão se relaciona com a ideia de que não se pode alterar as regras do jogo após o início da partida, e assim busca garantir a honestidade e a normalidade eleitoral, e até mesmo a igualdade entre candidatos, os quais em tese não podem ser beneficiados pela tentativa de modificação normativa. $\mathrm{O}$ dispositivo referido consagra o princípio da anualidade, o qual será oportunamente debatido.

Pertinente, por fim, apontar que sendo o ramo, como já exaustivamente repisado, integrante dos Direitos Humanos, seu arcabouço se encontra sedimentado não só na Constituição e na legislação interna, como também nos tratados internacionais.

Assim, nada obsta que se busque sua interpretação e teorização também junto à Convenção Americana de Direitos Humanos e à Declaração Universal dos Direitos Humanos, dentre outros instrumentos. Igualmente, uma vez violados direitos políticos, passível a arguição desta perante os sistemas regionais e globais de proteção.

\section{DELIMITAÇÃO DO DIREITO ELEITORAL}

\footnotetext{
${ }^{5}$ Artigo 16, Constituição da República Federativa do Brasil de 1988.
} 
Conforme visto, os direitos políticos possuem normas dotadas de generalização, e integram os direitos humanos e fundamentais de defesa do indivíduo em relação ao Estado, servindo como forma de garantir, regular, e limitar o exercício da soberania popular, estabelecendo nominalmente direitos que podem ser exigíveis por parte dos votantes.

Todavia, não há, em matéria de direitos políticos, previsão analítica de como se dará efetivamente o sufrágio, a não ser a utilização do voto e o estabelecimento de predicados básicos a este. Quanto ao funcionamento dispositivo das eleições, este cabe ao ramo do direito eleitoral, o qual configura o objeto do presente tópico. Pois bem.

\subsection{O CONCEITO DE DIREITO ELEITORAL}

A Doutrina tem conceituado o tema como "as normas e os procedimentos que regulam o exercício do direito fundamental de sufrágio com vistas à concretização da soberania popular, à validação da ocupação de cargos políticos e à legitimação (GOMES, 2018b, p. 50).

Marcos Ramayana de modo mais analítico, descreve precisamente o objeto sobre o qual se debruça tal braço normativo:

O Direito Eleitoral é um conjunto de normas jurídicas que regulam o processo de alistamento, filiação partidária, convenções partidárias, registro de candidaturas, propaganda política eleitoral, votação, apuração, proclamação dos eleitos, prestação de contas de campanhas eleitorais e diplomação, bem como as formas de acesso aos mandatos eletivos através dos sistemas eleitorais (RAMAYANA, 2018, p. 13).

Parece acurada a definição de "normas e procedimentos que organizam e disciplinam o funcionamento do poder de sufrágio popular, de modo a que se estabeleça a precisa adequação entre a vontade do povo e a atividade governamental" (RIBEIRO, 2000, p. 04).

O que nos parece ponto central quanto a conceituação neste tema, é a identificação das normas eleitorais como instrumento de efetivação dos direitos políticos e da soberania popular. Os direitos políticos compreendem normas gerais que resguardam justamente a soberania popular, ou seja, a imposição de que cabe ao povo definir a sua representação, e que sem esta definição não há legitimidade política.

Por sua vez, as regras eleitorais têm uma essência instrumental, cujas normas, ao contrário das políticas, são mais específicas, e determinam a estruturação ordinária do modo como se dará o sufrágio, o qual já foi atribuído pela Constituição, ao voto. Essa linha de 
interpretação, instrumental deve nortear a produção, hermenêutica e jurisdição da seara eleitoral.

Ora, tendo esse ramo o objetivo de auferir a vontade popular soberana, a produção e alteração legislativa de seus diplomas deve, em tese, abster-se de promover qualquer medida que torne o sufrágio menos democrático, que diminua sua autenticidade ou que afaste em qualquer análise do povo, como conjunto de cidadãos, o poder de escolha. Igualmente, essa produção legal deve se esforçar em potencializar a legitimidade, privilegiando medidas que incrementem a participação política e a genuinidade do procedimento de sufrágio.

O mesmo se dá em relação à interpretação do ramo. Um preceito essencial de compreensão é o de aproveitamento do voto, segundo o qual o objetivo precípuo da Justiça Eleitoral é de fazer valer a vontade do votante, pois "de forma similar ao Direito Penal, que trata do princípio básico do in dubio pro reo, no âmbito do Direito Eleitoral deve-se adotar o princípio do in dubio pro voto" (RAMAYANA, 2018, p. 22).

Com isso não se pretende defender que o voto deve prevalecer independentemente da normalidade e da justa aplicação das normas eleitorais. Até porque a eleição não tem o condão de ratificar eventuais ilícitos cometidos pelo eleito. Somente deve-se pontuar claramente que a teoria das nulidades na matéria em espécie precisa necessariamente conterse à efetivar aquele ideal de voto livre, secreto, e com valor igual para todos. Inadmissível qualquer julgamento meritório em relação ao voto.

Assim se orienta também a jurisdição eleitoral, na qual é imperioso e acautelatório que a Justiça tenha o tato de não viciar o pleito justamente na tentativa de legitimá-lo. Questão tormentosa é o modo de se garantir essa legitimidade, afinal, ao constatar-se uma irregularidade, ainda mais quando passível de influenciar o resultado do pleito, imperioso que por parte do Judiciário haja a responsabilização, com a aplicação de sanção, se o caso.

Ao mesmo tempo, se faz necessário que a apuração de qualquer ilícito eleitoral, embora célere, se dê com prudência extrema, pois os impactos reverberarão na obtenção de votos, o que inclusive se intensifica em tempos de mídias sociais e internet, já que a intensificação das informações "decorrentes dos avanços tecnológicos verificados nas últimas décadas geraram profundas transformações que contribuem para a efetivação do regime democrático" (RAIS, 2018, p. 86).

Ao se analisar os direitos político e eleitorais, evidentemente, nota-se uma grande zona de convergência. Todavia, não nos parece adequada a concepção de que um destes ramos contenha o outro, a qual parece emanar de algumas posições doutrinárias. 
Em tempo, essa definição possui relevância e consequentemente merece análise, pois, a depender de sua classificação, diverso o trato jurídico a que se submete cada ramo. Ora, sendo os Direitos Políticos também humanos e fundamentais, variados predicados se extraem: sua previsão remete à centralidade do ordenamento, e sua posição hierárquica é das mais elevadas, o que influencia a possibilidade de sua alteração, sendo que esta, ocorrendo, deve obedecer à vedação ao retrocesso.

Também primordial que em havendo violação de direitos políticos, imediatamente passível que se busque guarida junto aos sistemas internacionais de proteção aos Direitos Humanos.

Noutro giro, esse cenário não se aplicaria ao ramo Eleitoral. As normas deste feixe seriam, em tese, infraconstitucionais, sendo passíveis de mais flexível violação. Nesse ponto, cabe esclarecer que o Código Eleitoral ${ }^{6}$, por ser cronologicamente anterior à Constituição, foi por esta recepcionada como lei ordinária em sua integralidade, com a exceção do mote de organização e competência da Justiça e dos Juízes Eleitorais, recepcionado como lei complementar.

Ainda assim, as normas de direito eleitoral poderiam ser mais facilmente alteradas, em comparação aos direitos políticos externados pela Constituição, com a pertinente distinção de que caso tal modificação acarrete mudança ao processo eleitoral, esta não será aplicada ao pleito realizado em até um ano, como visto.

Já por não serem compreendidas em essência no rol de direitos humanos, não admitiriam, em tese, a possibilidade de arguição internacional, a não ser por violação reflexa.

Retomando-se à relação entre os debatidos ramos, nos parece evidente serem estes distintos, possuindo todavia inquestionável zona de intersecção. Assim pode-se identificar três conceitos nítidos: os direitos políticos puros ou genuínos, os direitos político-eleitorais, e os direitos eleitorais propriamente ditos. A maior parte dos direitos políticos são também eleitorais, já nos eleitorais, uma parcela menor em relação ao todo seria concomitantemente política. Evidentemente, em quantidade, muito maior é o número de normas eleitorais em relação às políticas. Todavia, estas últimas são mais densas, possuindo maior carga principiológica e abstrata.

Caso esta concepção fosse visualizada de modo diagramal, ter-se-iam duas formas geométricas. A primeira e de menor tamanho compreende os Direitos Políticos, a segunda e maior compreenderia o Direito Eleitoral. Já a intersecção compreenderia grande parte da

\footnotetext{
${ }^{6}$ Lei ${ }^{\circ}$ 4.737, de 15 de julho de 1965
} 
primeira figura, e um trecho bem menor da segunda.

As previsões constitucionais relativas aos direitos políticos que erigem a soberania popular como fundamento republicano podem ser tidas como puramente políticas, posto que incorpóreas. Embora indubitavelmente possuam hierarquia de destaque, dependem de normas que as ponham em prática.

A grande maioria dos direitos políticos, noutro lado, integram também as normas eleitorais, pois estabelecem determinados mandamentos relativos aos procedimentos do pleito, os quais não podem ser contraditos pela legislação, nem violados na dimensão fática. Tais normas são estipuladas pelos direitos políticos mas aparelhadas pelas regras eleitorais.

Finalmente, há diversas normas deste último ramo que obviamente não podem ser tidas como políticas. Uma regra que estabelece, por exemplo, a contagem de um prazo relativo à eleição evidentemente não deve ser agasalhada pelo rol dos Direitos Humanos e Fundamentais. São puramente procedimentais, assim, meramente eleitorais.

\section{APONTAMENTOS SOBRE A HERMENEUTICA INSTRUMENTAL DOS PRINCÍPIOS DO DIREITO ELEITORAL}

Diante do ideal de instrumentalidade das normas eleitorais, tendo-se em mente a noção de que estas, desde sua fonte até sua aplicação devem consumar, em última análise, a soberania popular, prezando sempre por garantir a mais intensa efetivação dos direitos políticos, deve-se dar também essa roupagem hermenêutica aos princípios eleitorais, os quais “ordenam quealgo seja realizado na maior medida possível dentro das possibilidades jurídicas e fáticas existentes" (ALEXY, 2009, p. 90-91), e portanto otimizam a operação do ramo.

Nesse contexto, passaremos a tratar de tais preceitos. Antes de mais nada, entretanto, necessárias se faz uma ressalva. No presente artigo como um todo e neste tópico em especial, buscar-se-ão interpretações relativas à forma sobre a qual se emolduram diversos princípios em relação à direitos políticos ou eleitorais - bem como discutem-se estes. Não se quer, todavia, conduzir à errônea ideia de um panprincipiologismo, como se fosse indispensável a qualquer dos citados ramos uma vasta elaboração principiológica.

Luiz Carlos dos Santos Gonçalves contemporaneamente percebeu essa tendência, e contribuiu à discussão de maneira tão certeira que se faz mister citá-lo em sua integralidade, nos seguintes termos:

O Brasil pós-1988 experimentou uma proliferação acrítica de princípios, criados de modo subjetivo e com metodologia incerta, dutos para um indesejado ativismo dos 
operadores do Direito, substituindo a norma legislada, sem indícios de inconstitucionalidade, por aquelas que eles gostariam que tivesse sido feita. A abstração e generalidade próprias dessas modalidades normativas propicia alargado contrabando ideológico do intérprete, que porá ênfase em versões mais condizentes com sua visão de mundo e interesses. Assim é que um moralista eleitoral, pecha que se costuma apor sobre os entusiastas da Lei da Ficha Limpa, por exemplo, não tardará em indicar a boa governança como princípio eleitoral, ao passo que alguém que não se afina com as restrições daquela lei complementar dirá que ela ofende o princípio da elegibilidade (GONÇALVES, 2018, p. 41).

Em verdade, o que se defende é verdadeiramente o oposto. Sem advogar outra falsa noção de que elege-se um ou outro princípio acima dos demais, quer-se meramente discutir, por meio deste tema, a possibilidade de que sejam o direito eleitoral e as normas de direitos políticos operadas com a finalidade de efetivar a soberania popular. Assim, busca-se interpretar os princípios de forma menos complexa, com uma intenção finalística: qual seja, a de servirem como instrumentos em favor da legitimidade do poder que realmente deve emanar do povo, e portanto assim precisa ser garantido.

É pertinente que:

Não é qualquer um e nem é qualquer coisa que pode ser princípio. Do contrário, teremos que abandonar a tese dominante de que princípios são normas. [...] é ainda possível - e necessário - ressaltar que não se pode partir do princípio para resolver um caso. Isso seria fazer raciocínios teleológicos. Haverá uma regra (norma em geral) apta a resolver o caso a partir de uma reconstrução principiológica (reconstrução da história institucional). Esse é o espaço e o papel dos princípios (STRECK, 2009, p. 526).

Portanto o objetivo aqui deflagrado foi o de, por meio de um ponto de vista instrumental, discutir a principiologia política e eleitoral. Para potencializar esse mote optouse por tratar de maneira mais abrangente determinados preceitos que, embora trazidos pela Doutrina, não necessariamente são pelo presente autor incluídos como tais. Assim, postergase a discussão a respeito da inclusão ou não destes ao rol de "Princípios do Direito Eleitoral" formalmente considerados, em prol de uma discussão relativa à utilização segunda uma hermenêutica instrumental daqueles que são considerados princípios eleitorais e dos direitos politicos. Feito esse interregno, oportuno que se analisem em espécie os protagonistas desta abordagem.

O Princípio da Igualdade, a priori, com respaldo no artigo $5^{\circ}$ constitucional, mas também no repisado artigo 14, dispõe que são todos iguais diante da lei. Esse preceito como já visto deriva de norma de direitos políticos, emanando desse ramo também para o Direito Eleitoral. Em uma interpretação mais calcada naquele primeiro feixe jurídico, a igualdade atribui não só a mesma carga a ser conferida a todos os votantes (conforme um contexto de decisão majoritária), como também se relaciona com o conceito de universalidade do 
sufrágio, que deve englobar - igualmente, e portanto sem distinção dentro de grupos que compreendam indivíduos na mesma situação jurídica - todos os cidadãos.

Pela perspectiva instrumental daquela segunda área, o mandamento adquire novos contornos, sendo que duas vertentes devem extrair-se. Primeiro, não pode o Estado dispensar tratamento distinto para sujeitos em uma mesma situação jurídica, e em segundo lugar, necessário se faz que o Poder Público promova a efetivação prática desse conceito de igualdade, por posturas que concretizem esse ideal. É então gerada uma “imposição de existência da igualdade de chances nas disputas eleitorais. Sendo assim, o Estado e a Legislação devem facilitar que candidatos e partidos políticos possam concorrer de forma não fictícia" (VASCONCELOS; SILVA, 2018, p. 25).

Desse modo, há uma concepção negativa do princípio, segundo a qual deve o Estado deixar de favorecer (ou de prejudicar) sujeitos eleitorais, atuando de maneira passiva, com a mais absoluta neutralidade em relação aos candidatos, partidos políticos, coligações ou até mesmo ideologias. Essa ideia se encontra alinhada com aquela determinação política de que o voto terá valor igual para todos.

Há ainda a concepção positiva desse preceito de igualdade, de modo que cabe ao Poder Público tomar providências para que se efetive em maior intensidade possível os contornos de soberania popular. É nessa direção a edição de diplomas normativos que, a título de exemplo, limitam os gastos de campanha ou promovem a inclusão obrigatória de percentual de cada sexo em partidos políticos. Retomando-se aquela analogia lockeana do corpo composto em movimento, o Estado deveria agir no sentido de balancear o pleito, já que:

Há um pressuposto implícito e importante de que a influência das partes sobre o movimento do todo é igual. Se alguma das partes tem mais massa do que outras, ou se seus movimentos são mais agitados, não há, naturalmente, mais nenhum motivo para supor que o coro irá mover-se em conformidade com a direção do maior número de partes (WALDRON, 2003, p. 160).

O que se deve ter em mente, diante do raciocínio ora externado, é que, se o fim máximo do pleito será a concessão de legitimidade aquele determinado autenticamente pela maioria, a intervenção jurídica deve pautar-se estritamente na efetivação dessa autenticidade. Quanto a igualdade em específico, o princípio deve funcionar como vetor, seja na elaboração das leis seja em sua aplicação, no sentido de possibilitar maior autenticidade aos resultados externados pela votação. É nessa toada que restaria adequada a coibição de abusos nos gastos de campanha, por exemplo. 
O Princípio Democrático também deriva de regras de direitos políticos, e orienta o sistema jurídico eleitoral brasileiro como um todo, para não citar a própria ordem constitucional. Segundo esse preceito, e não obstante as diversas mutações pelas quais o termo "democracia" passou historicamente, deriva o conceito de um governo que verdadeiramente emane do povo. Não à toa, "Mais que princípio inscrito na Lei Magna, a democracia constitui fundamento e valor essencial das sociedades ocidentais, definindo sua estética, o modo como elas existem e operam" (GOMES, 2018b, p. 68).

O preceito de Democracia pode extrair-se da Constituição como um todo, mas também é esculpido por normas como aquelas dos já citados artigo $1^{\circ}$, parágrafo único, e 14 , caput. Finalmente, se relaciona com a percepção comumente atribuída à Democracia o mandamento de ser direto o voto, o que garante mais estreita legitimidade ao eleito.

Outro princípio que se encontra sedimentado em matéria política, mas que influencia intensamente temas eleitorais é aquele do sigilo das votações. Essa ordem busca garantir a honestidade, seja como salvaguarda para o Eleitor (já que espera-se que com o segredo sufragará sem temer represálias), seja como medida impeditiva de captação sufrágio, na tentativa de evitar "o suborno, a corrupção e a intimidação do eleitor" (GOMES, 2018a, p. 99). Segundo a perspectiva instrumental que o presente trabalho adota, a regra deve contribuir para uma espontaneidade na aferição da vontade popular, devendo coibir-se não só as claras condutas que desnudem o significado do voto, como qualquer intervenção legislativa ou jurídica que irrazoadamente interfira na vontade autêntica do votante por divulga-la.

Há ainda que se citar como princípio de direitos políticos, mas que se aproxima quase por inteiro do Direito Eleitoral aquele da Anualidade ou Anterioridade Eleitoral, previsto pelo artigo 16 constitucional. Conhecido como preceito de "rules of the game", dispõe que a lei que alterar o processo eleitoral até entrará em vigor na data de sua publicação, mas não se aplicará à eleição que ocorra até um ano desde a sua vigência, como forma de proteção individual ao cidadão-eleitor, detentor originário do poder exercido pelos representantes eleitos ${ }^{7}$.

É bastante óbvia a intenção principiológica de salvaguardar a estabilidade, a equidade e a segurança do sufrágio, para evitar que o integrante da máquina pública promova alterações artificiosas durante o sufrágio, seja em benefício próprio seja no de outrem. Igualmente, o ideal do preceito é de que o operador eleitoral não seja surpreendido por estas

\footnotetext{
${ }^{7}$ STF - ADI no 3.685-8 - Rel. Min. Cármen Lúcia - DJ 10-8-2006.
} 
modificações. Popularmente diz-se que não se pode alterar as regras do jogo no decorrer da partida.

Sucintamente, "Por expressa determinação constitucional, não há vacatio legis, já que a lei entra em vigor na data de sua publicação, mas, ainda assim, há suspensão de eficácia da lei na parte em que dispuser sobre "processo eleitoral'" (MACHADO, 2018, p. 23). O princípio tem total consonância com nossa defesa de ser a matéria eleitoral passível de hermenêutica instrumental, na qual deve sua interpretação efetivamente garantir o exercício da soberania popular.

Desse modo, apenas duas arestas do tema merecem ser aparadas. A priori, a abrangência de quais inovações submetem-se ao período de anualidade. José Jairo Gomes, por exemplo, tem o entendimento de que "o princípio da anualidade eleitoral não só restringe a plena eficácia de norma legal, mas também - em situações específicas - a da jurisprudência, limitando, portanto, o Legislador e o Judiciário Eleitoral” (GOMES, 2018b, p. 298). Doutro lado, o já citado Luiz Carlos dos Santos Gonçalves denuncia que a regra de anualidade não pode ser tida como princípio, naquela discussão já indicada, e portanto:

\begin{abstract}
A interpretação extensiva que se deve fazer dessa regra, por exemplo, aplicando-a também às alterações da jurisprudência eleitoral ou para disposições eleitorais de caráter não exclusivamente relativo ao processo das eleições, não infirma esta solução. Se há um princípio em jogo, é o da segurança jurídica, do qual a regra da anualidade é uma concretização (GONÇALVES, 2018, p. 41).
\end{abstract}

Conforme já se pontuou, o presente texto não tem a pretensão de tratar dessa classificação, mas tão somente da análise dos princípios como veículos efetivadores dessa instrumentalidade das regras eleitorais. Assim, resta mais alinhada a tal hermenêutica, a primeira posição, de modo a fazer incidir em todas as instâncias a necessidade de que a eventual alteração ao procedimento seja precedida de um ano para aplicação.

A segunda aresta que desponta é justamente a definição daquilo que será ou não compreendido como processo eleitoral. Ora, independentemente de se considerar vedada a incidência de inovações apenas para leis ou também para as decisões jurisprudenciais, essa imposição só se fará presente quanto alterar o processo eleitoral.

Para uma abstração mais conservadora, somente as normas eleitorais realmente processuais seriam objeto desse regramento, ou seja, aquelas que tratem de um "processo eleitoral”. Alguns autores, por sua vez, têm se postado junto à ideia mais abrangente, de que toda regra que tutele os fenômenos eleitorais que ocorram desde as convenções partidárias até a diplomação dos eleitos deviam submeter-se à anterioridade obrigatória. 
Em verdade, nenhuma das correntes nos parece adequada. A mera característica processualística de uma regra não garante, integralmente, a sua relevância em relação ao bem jurídico aqui debatido - a segurança jurídica. Igualmente, ao atribuir-se a anterioridade indiscriminadamente, pode-se promover o atraso da aplicação jurídica a temas sem pertinência.

Por uma perspectiva justamente finalística somente as alterações que interferissem na livre manifestação soberana do povo deveriam ver sua incidência postergadas pelo princípio. Mais acirradamente, seria concebível que uma norma que defina tão somente aspecto procedimental do pleito, e não impacte de forma alguma em seu resultado, nem estreite o horizonte de manifestação dos votantes, não seja atingida pela anualidade, ainda que processual. Princípio ainda que nos parece particularmente caro ao que aqui se discute é o da legitimidade, lisura, autenticidade ou honestidade eleitoral. Proveniente do ramo dos direitos políticos, e calcado no artigo $14, \S 9^{\circ}$ da Lei Maior, o qual como visto relega à Lei Complementar determinar inelegibilidades que protejam a probidade administrativa, a moralidade para o exercício do mandato e resguardem a legitimidade contra a influência do poder econômico e político, este possui inegavelmente repercussões mais amplas.

Entendemos ser esta (a autenticidade) qualidade conclusiva atribuída ao pleito que, a um só tempo, respeite as normas eleitorais - possua legalidade -; que seja apto a aferir a vontade que prevalece no conjunto de cidadãos; e ainda cujo o qual a intenção dos votantes não tenha sido artificiosamente induzida.

Embora esse preceito possa ser objeto de aprofundamentos, a questão relacionada aos fins do presente texto está na concessão ou não, por parte do judiciário, de legitimidade a uma eleição. Ora, com a interferência jurídica, evidentemente pode decorrer a alteração do resultado do pleito. Por sua vez, ao ser um pleito apreciado jurisdicionalmente e em ocorrendo a não- concessão de autenticidade, poderia ser esse, em hipóteses extremas, anulado.

Assim, diante da pertinente possibilidade de que a intervenção jurídica ao ramo, ainda que justamente na tentativa de moralizá-lo, possibilite influência, o que pode gerar inclusive o desbalanceamento do pleito, deve-se tratar com tato qualquer interferência. Assim, deve o detentor de jurisdição atuar em máxima cautela.

Propositalmente, deixou-se para o final da lista o Princípio do Aproveitamento do Voto. Este não encontra lastro em direitos políticos, embora evidentemente integre o ramo como forma de garantir a intenção do votante, mas tem fundamento no Código Eleitoral, que 
reza: "Na aplicação da lei eleitoral o juiz atenderá sempre aos fins e resultados a que ela se dirige, abstendo-se de pronunciar nulidades sem demonstração de prejuízo"8.

O princípio em tela fundamenta a análise instrumental do presente trabalho, ou seja, a noção de que toda a operação jurídico-eleitoral deve nortear-se pela garantia ao voto. Na jurisdição, impera a presunção de legitimidade do sufrágio. Portanto "de forma similar ao Direito Penal, que trata do princípio básico do in dubio pro reo, no âmbito do Direito Eleitoral deve-se adotar o princípio do in dubio pro voto" (RAMAYANA, 2018, p. 22).

Como já visto, a teoria das nulidades em matéria de sufrágio reveste-se da mais necessária cautela, sendo imprescindível que em toda a aplicação jurídica, resguarde-se à intenção do votante. Daí é que decorre o ponto central de controvérsia. Em verdade, o que se tem em todo o trabalho é o atrito entre a autenticidade que precisa ser preservada quanto ao voto, e a roupagem jurídica tendente a proteger a sua genuinidade. Ou seja, deve essa intenção do votante, ainda que viciada, prevalecer?

Em nosso sentir, a resposta seria negativa. É evidente que a instrumentalidade dos direitos eleitorais resguarda tanto ao votante quanto ao votado o direito subjetivo de influenciar o processo democrático, sendo impensável que pela interpretação normativa se mitigue essa garantia. Ainda assim, ou melhor, justamente em razão dessa garantia, com a indiscutível presença de ilegalidades, deve seu autor ser responsabilizado. Se essa responsabilização acarretar o indeferimento do registro de um candidato, a recontagem de votos de um político ou à cassação do mandato de um eleito, essas consequências também são compreendidas pelo aproveitamento do voto.

Não poderia ser diferente, já que a hermenêutica aqui defendida é finalista, mas não retificadora. Ou seja, embora o voto deva ser prezado com a mais alta intensidade, não é o mesmo absoluto, nem tem o condão de dirimir ilegalidades cometidas antes ou após sua deliberação. Além do mais, o preceito ora em análise não incide solitariamente ao sistema, devendo a otimização das regras dele decorrente se dar também levando-se em conta os demais princípios, como em especial o da Autenticidade.

Quando a intenção do votante se revestir de ilicitude, não mais resta a manifestação de vontade desse voto decorrente autêntica, nem o poder com ele transferido legítimo. Em verdade, a imposição de sanções ao eleitor ou ao candidato quando da ocorrência de violações, independentemente de ser ou não aquele eleito, é também uma incidência do Princípio do Aproveitamento do Voto, aqui como forma de salvaguardar a manifestação dos

\footnotetext{
${ }^{8}$ Artigo 219 do Código Eleitoral, Lei no 4.737 de 1965.
} 
demais votantes e votados, os quais merecem ter sua atuação autêntica no pleito resguardada.

\section{CONSIDERAÇÕES FINAIS}

O presente trabalhou buscou elucidar determinadas relações comumente sombrias quanto ao tema dos direitos políticos e eleitorais. Diante da interpretação instrumental dispensada aos respectivos ramos jurídicos, como forma de que se alcance uma efetiva atribuição - justa e legítima - de soberania aos apontados como eleitos em determinado pleito, se faz imediatamente necessário que se garanta a validade de tal apontamento.

A hermenêutica instrumental deve, portanto, servir como baliza, mas também como justificativa à intervenção da Justiça às eleições, a qual merece ser intentada somente a fim de expurgar práticas ilícitas. O que se tem, em verdade, é uma espécie de decisão entre escolhas com resultados igualmente trágicos. De um lado, a aplicação da norma limita e influencia a decisão do votante; de outro, a não-aplicação daquela permite a proliferação de condutas que igualmente irão artificiosamente promover impactos na vontade genuína do eleitor.

Assim, como forma de proteger a eficácia do direito eleitoral, ou seja, a fim de que se alcance por meio deste a efetivação de uma soberania popular, que para além de autêntica precisa ser legítima, impõe-se à necessidade da tutela jurídica. Todavia, esta se verá limitada, quanto ao seu alcance, justamente à instrumentalidade que a dá causa, não podendo, sob hipótese alguma, os princípios eleitorais serem interpretados ou aplicados com o fim de dar à sistemática do sufrágio uma roupagem que torne menos intensa a soberania popular decorrente.

\section{REFERÊNCIAS}

ALEXY, Robert. Teoria dos Direitos Fundamentais. Trad. Virgílio Afonso da Silva. $1^{\text {a }}$ ed. São Paulo: Malheiros, 2008.

BASTOS JUNIOR, Luiz Magno Pinto; SANTOS, Rodrigo Mioto dos. Levando a sério os direitos políticos fundamentais: inelegibilidade e controle de convencionalidade. Rev. direito GV, São Paulo, v. 11, n. 1, p. 223-225, jun. 2015. Disponível em <http://www.scielo.br/scielo.php?script=sci_arttext\&pid=S1808-

$24322015000100223 \& \operatorname{lng}=$ pt\&nrm=iso>. acessos em 14 maio 2020.

BRASIL. Constituição (1988). Constituição da República Federativa do Brasil. Brasília, 5 
$\begin{array}{llll}\text { de } & \text { outubro } & \text { de } & \text { Disponível }\end{array}$

em:

<http://www.planalto.gov.br/ccivil_03/constituicao/constituicaocompilado.htm>. Acesso em 05 jun. 2019.

. Lei Complementar no 64/90. Brasília, 18 de maio de 1990. Disponível em:

<http://www.planalto.gov.br/ccivil_03/leis/lcp/lcp64.htm〉. Acesso em 14 jun. 2019.

- Lei $\mathbf{n}^{\mathbf{0}}$ 4.737/65. Brasília, 15 de julho de 1965. Disponível em:

<http://www.planalto.gov.br/ccivil_03/leis/14737.htm>. Acesso em 13 jun. 2019.

- Lei $\mathbf{n}^{\mathbf{0}}$ 9.504/97. Brasília, 30 de setembro de 1997 Disponível em:

<http://www.planalto.gov.br/ccivil_03/LEIS/L9504.htm>. Acesso em 13 jun. 2019.

GOMES, José Jairo. Crimes Eleitorais e Processo Penal Eleitoral. $3^{\text {a }}$. ed. São Paulo: Atlas, 2018.

GOMES, José Jairo. Direito Eleitoral. 14. ed. São Paulo: Atlas, 2018.

GONÇALVES, Luiz Carlos dos Santos. Direito Eleitoral. $3^{a}$ ed. São Paulo: Atlas, 2018.

MACHADO, Raquel Cavalcanti Ramos. Direito Eleitoral. 2ª ed. São Paulo: Atlas, 2018.

MARTINS, Flávio Nunes Alves. Curso de Direito Constitucional. 3. ed. São Paulo: Saraiva, 2019.

MESSA, Ana Flávia; SIQUEIRA NETO, José Francisco; BARBOSA, Susana Mesquita (Coordenadores). Transparência Eleitoral. 1ª ed. São Paulo: Saraiva, 2015.

RAIS, Diogo (Organizador). Direito Eleitoral Digital. São Paulo: Revista dos Tribunais, 2018.

RAMAYANA, Marcos. Direito Eleitoral. 16. ed. Rio de Janeiro: Impetus, 2018.

RAMOS, André de Carvalho. Curso de Direitos Humanos. 4ª ed. São Paulo: Saraiva, 2017.

RIBEIRO, Fávila. Abuso de Poder no Direito Eleitoral. 2a ed. Rio de Janeiro: Forense, 2000.

SILVA, José Afonso da. Curso de Direito Constitucional Positivo. $28^{a}$ ed. São Paulo: Malheiros, 2007.

STRECK, Lenio Luiz. Aplicar a "letra da lei" é uma atitude positivista? Disponível em: <https://siaiap32.univali.br/seer/index.php/nej/article/view/2308>. Acesso em: 06 jul. 2019.

VASCONCELOS, Clever; SILVA, Marco Antonio da. Direito Eleitoral. São Paulo: Saraiva 
Educação, 2018.

WALDRON, Jeremy. A Dignidade da Legislação. 1ª . ed. São Paulo: Martins Fontes, 2013. 